\title{
Analisis Kualitatif Senyawa Metabolit Sekunder Ekstrak Daun Gulma Siam (Chromolaena odorata L.) di Kota Langsa, Aceh
}

\author{
Bayu Andika ${ }^{1}$, Halimatussakdiah ${ }^{1 *}$, dan Ulil Amna ${ }^{1}$ \\ ${ }^{1}$ Program Studi Kimia Fakultas Teknik Universitas Samudra \\ Jl. Meurandeh, Langsa Aceh 24416, Indonesia \\ *Corresponding author: halimatussakdiah@unsam.ac.id
}

\begin{abstract}
ABSTRAK
Indonesia adalah salah satu negara mega biodiversitas yang mempunyai keanekragaman hayati tertinggi kedua setelah Brazilia. Dari 40.000 spesies tumbuhan yang ada di dunia, sebanyak 30.000 spesies dijumpai di Indonesia dan tidak kurang dari 1000 spesies diantaranya memiliki khasiat sebagai obat salah satunya adalah tumbuhan Gulma Siam (Chromolaena odorata L.). Tumbuhan C. odorata termasuk kedalam Genus Chromolaena DC., yang mempunyai manfaat diantanranya untuk antidiare, astringen, antisplasmodik, antihipertensi, antiinflamasi, tonik diuretik, antipiretik, tonik jantung, dan lain-lain. Penelitian ini bertujuan untuk menganalisis adanya senyawa metabolit sekunder pada ekstak daun kering dan segar $C$. odorata. Berdasarkan hasil uji pada daun kering $C$. odorata terdapat senyawa metabolit sekunder seperti saponin, flavonoid, fenol dan tannin. Sedangkan hasil uji daun segar $C$. odorata terdapat senyawa metabolit sekunder seperti alkaloid, saponin, flavonoid, fenol dan tanin.
\end{abstract}

Kata Kunci: Chromolaena odorata, Gulma Siam, Metabolit Sekunder, dan Aceh

\section{PENDAHULUAN}

Indonesia merupakan salah satu negara yang kaya dengan berbagai jenis flora dan fauna.Negara yang mempunyai keanekragaman hayati tertinggi keda setelah Brazilia (Amerika Selatan) ini memiliki 30.000 spesies dari 40.000 spesies tumbuhan yang ada di dunia, dan tidak kurang dari 1000 spesies diantaranya memiliki khasiat sebagai obat yang sudah dipergunakan dalam pengobatan tradisional secara turun temurun oleh berbagai suku di Indonesia [1]. Salah satu tumbuhan yang sering digunakan masyarakat sebagai obat tradisional adalah tumbuhan Gulma Siam (C. odorata).

Chromolaena odorata merupakan tumbuhan yang hidup di daerah tropis maupun sub tropis, yang tumbuh pada berbagai jenis tanah dengan baik dan apabila mendapat cahaya matahari yang cukup maka akan tumbuh lebih baik lagi [2]. Organ utama yang paling banyak digunakan sebagai obat tradisional untuk berbagai macam penyakit adalah bagian daun. Daun C. odorata menghasilkan minyak essensial yang mengandung cadinena, $\alpha$-pinena, $\beta$-cariofillena, camphora, dan isomer candinol, serta daun $C$. odorata mengandung beberapa senyawa utama seperti saponin, fenol, tanin, steroid dan flavonoid [3].

Tumbuhan $C$. odorata memiliki ciri: tumbuhan herba bertahun, semak abadi, tinggi 1,5-2,0 m, kadang-kadang mencapai ketinggian maksimum $6 \mathrm{~m}$ (sebagai pemanjat tanaman lain) [4], batang lurus, bernas, rapuh dan mudah bercabang, memiliki tiga daun, daun berbentuk segitiga bulat telur, dan memiliki akar pendek yang dangkal, semak berkayu yang dapat berkembang dengan cepat, Gulma ini merupakan pesaing agresif dan memiliki efek allelopati [5]. C. odorata telah dinominasikan sebagai spesies penyerbu terburuk di dunia oleh Persatuan Internasional untuk Conservation of Nature [6].

Klasifikasi $C$. odorata meliputi: [4]:

$\begin{array}{ll}\text { Kingdom } & \text { : Plantae } \\ \text { Subkingdom } & \text { : Tracheobionta } \\ \text { Superdivisi } & : \text { Spermatophyta } \\ \text { Divisi } & : \text { Magnoliophyta } \\ \text { Kelas } & : \text { Magnoliopsida } \\ \text { Subkelas } & : \text { Asteridae } \\ \text { Ordo } & : \text { Asterales } \\ \text { Famili } & : \text { Asteraceae } \\ \text { Genus } & : \text { Chromolaena DC. } \\ \text { Spesies } & : \text { Chromolaena odorata (L.) }\end{array}$

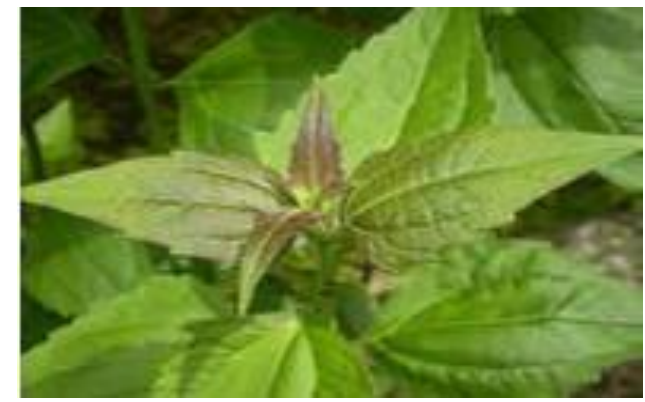

Gambar 1.Tumbuhan C. odorata

Di Indonesia, selain dikenal dengan nama Gulma Siam juga disebutkan dengan nama: tekelan, pokok selaput tunggul; Aceh: sikhohkhoh, seurapok dan serunei; Sumatera 
Utara: lenga-lenga; Makassar: laruna, kopasanda [7]; Sunda: Kirinyu [3]; dalam bahasa Inggris dikenal sebagai Siam Weed, Christmas Bush, dan Common Floss Flower [8], Nigeria: Siam Weed, Awolowo [9]; Malaysia: pokok kapal terbang [6]. Penyebaran Gulma Siam, awalnya diketahui berasal dari Amerika Selatan dan Tengah [10], kemudian menyebar ke daerah tropis Asia, Afrika, Pasifik, dan Indonesia [5]. Di Indonesia tumbuhan ini memiliki beberapa sifat obat dan aromatik yang digunakan sebagai obat tradisional [6].

Gulma Siam berkhasiat sebagai antidiare, astringen, antispasmodik (pereda kejang pada saluran cerna), antihipertensi, antiinflamasi (mengurangi radang), tonik diuretik (pelancar urin), antipiretik (pereda demam) dan tonik jantung [11], digunakan untuk penyakit kulit dan perawatan penyembuhan luka [12], luka bakar manusia, luka jaringan lunak, luka ulserasi, luka pasca melahirkan dan juga untuk pengobatan gigitan lintah, gangguan pencernaan dan infeksi kulit [13], antiprotozoal (anti biotik), antitrypanosom, antibakteri, antijamur, dan hepatotropik (pereda radang hati) [14], amenore, radang selaput lendir hidung, diabetes, demam, pertusis dan rematik, dan sebagai obat cacing [15], di bidang pertanian dapat digunakan sebagai pupuk organik, biopestisida serta herbisida dan di bidang medis secara tradisional dapat digunakan sebagai obat batuk dan menghentikan pendarahan [7], obat kumur untuk pengobatan sakit pada tenggorokan, obat malaria, antimikroba, sakit kepala, dan diuretik [16].

Penelitian ini dilakukan untuk membuktikan kandungan metabolit sekunder (alkaloid, terpenoid, steroid, saponin, flavonoid, fenol, dan tanin) dalam daun $C$. odorata yang diambil dari Desa Meurandeh Dayah, Kecamatan Langsa Lama, Kota Langsa, Provinsi Aceh yang potensial digunakan sebagai obat. Dengan demikian, hasil penelitian diharapkan dapat menjelaskan secara ilmiah kandungan metabolit sekunder dari daun $C$. odorata beserta fungsi dari metabolit sekunder tersebut. Penelitian ini diharapkan bisa menjadi dasar diadakannya penelitian lanjutan tentang potensi senyawa metabolit sekunder daun $C$. odorata bagi kesehatan.

\section{BAHAN DAN METODE}

\section{Bahan}

Bahan yang digunakan dalam penelitian ini yaitu metanol, etil asetat, heksana, kloroform, asam sulfat, pereaksi Meyer, pereaksi Dragendorff,, pereaksi Wagner, pereaksi
Liberman-Bourchard, etanol $80 \%, \mathrm{HCl} 0,5 \mathrm{M}$, dan $\mathrm{FeCl}_{3}$.

\section{Metode}

\section{a. Penanganan Sampel}

Pengambilan daun tumbuhan Chromolaena odorata segar pada Maret 2019, di Gampong Meurandeh Dayah, Kecamatan Langsa Lama, Kota Langsa, Provinsi Aceh. Daun diambil sebanyak 20 gram. Kemudian 10 gram diambil untuk dikering anginkan dan dijaga agar tidak terkena sinar matahari secara langsung, setelah kering dihaluskan hingga diperoleh serbuk kering yang kemudian akan diekstraksi [17].

\section{b. Ekstraksi}

Daun kering dan daun segar $C$. odorata sebanyak 1 gram dihaluskan dan diekstraksi dengan metanol dengan metode maserasi selama 3 × 24 jam, maserasi diulang sampai filtratnya bersih. Larutan ekstrak disaring dan diuapkan dengan rotary evaporator untuk menghasilkan ekstrak metanol [17].

\section{c. Uji alkaloid}

Sekitar 1 gram masing-masing daun kering dan daun segar $C$. odorata dihancurkan lalu ditambahkan $1 \mathrm{~mL}$ amonia. Selanjutnya dimasukkan $10 \mathrm{~mL}$ kloroform, kemudian dihancurkan dan disaring. Filtrat ditambahkan 10 $\mathrm{mL}$ asam sulfat $2 \mathrm{~N}$, dikocok kuat-kuat, dibiarkan selama satu menit sampai larutan asam sulfat dan kloroform dipisahkan. Lapisan asam sulfat diambil dan dibagi menjadi tiga tabung reaksi dan setiap tabung reaksi diuji dengan pereaksi Meyer, Dragendorff, dan Wagner untuk menentukan keberadaan alkaloid. Penambahan reagen Meyer membentuk endapan putih, reagen Dragendorff menyebabkan endapan kemerahan, dan reagen Wagner menghasilkan endapan kuning. Hasil tersebut menunjukkan adanya alkaloid [17].

\section{d. Uji Terpenoid, Steroid, dan Saponin}

Masing-masing sebanyak 1 gram daun kering dan daun segar $C$. odorata ditumbuk halus, kemudian diekstraksi dengan metanol panas. Filtrat yang diperoleh dipekatkan dengan rotary evaporator untuk menghasilkan ekstrak metanol. Ekstrak metanol dipartisi dengan heksana. Ekstrak yang larut dalam heksana diuji dengan reagen Liberman-Bourchard. Warna biru atau hijau menunjukkan adanya steroid dan warna merah untuk terpenoid. Residu yang tidak larut 
dalam heksana ditambahkan air dan dikocok dengan kuat. Apabila ada busa stabil selama 30 menit menunjukkan adanya saponin, jika positif untuk saponin, larutan kemudian dihidrolisis dengan $\mathrm{HCl}$ dan diuji dengan pereaksi LibermanBourchard. Warna hijau atau biru menunjukkan adanya saponin steroid dan warna ungu atau merah menunjukkan adanya saponin terpenoid [17].

\section{e. Uji Flavonoid}

Daun kering dan daun segar $C$. odorata sebanyak 1 gram diekstraksi dengan metanol dan dipekatkan. Ekstrak metanol pekat dipartisi dengan heksana. Residu diekstraksi dengan 10 $\mathrm{mL}$ etanol $80 \%$, kemudian ditambahkan 0,5 mg serbuk magnesium dan $\mathrm{HCl}$ 0,5 M. Warna merah muda atau ungu menunjukkan adanya flavonoid [17].

\section{f. Uji Fenol}

Ekstrak metanol masing-masing sampel diuji dengan $\mathrm{FeCl}_{3}$. Tambahkan 3 - 4 tetes larutan $\mathrm{FeCl}_{3}$ ke dalam ekstrak, pembentukan warna hitam kebiruan menunjukkan senyawa fenol [17].

\section{g. Uji Tanin}

Sebanyak 1 gram ekstrak metanol sampel direbus dalam $10 \mathrm{~mL}$ air dalam tabung reaksi kemudian disaring. Tambahkan beberapa tetes $\mathrm{FeCl}_{3} \quad 0,1 \%$. Pembentukan warna hijau kecoklatan atau hitam kebiruan menunjukkan adanya tanin [17].

\section{HASIL DAN PEMBAHASAN}

Sampel daun $C$. odorata dalam penelitian ini diambil dari perkebunan kelapa sawit di Gampong Meurandeh Dayah, Kecamatan Langsa Lama, Kota Langsa, Provinsi Aceh. Sampel yang digunakan adalah sampel kering dan sampel segar yang diekstraksi dengan metanol. Ekstrak metanol tersebut kemudian dilakukan analisis kualitatif kandungan metabolit sekunder, meliputi alkaloid, terpenoid, steroid, saponin, flavonoid, fenol dan tanin. Berikut adalah hasil uji kulitatif dari senyawa tersebut:
Tabel 1. Hasil Analisis Kualitatif Senyawa Metabolit Sekunder Ekstrak Daun C. odorata.

\begin{tabular}{clcc}
\hline No & $\begin{array}{l}\text { Metabolit } \\
\text { Sekunder }\end{array}$ & $\begin{array}{c}\text { Daun } \\
\text { Kering }\end{array}$ & $\begin{array}{c}\text { Daun } \\
\text { Segar }\end{array}$ \\
\hline & Alkaloid & & \\
1 & - D & $x$ & $\checkmark$ \\
& - M & $x$ & $x$ \\
& - W & $x$ & $x$ \\
2 & Terpenoid & $x$ & $x$ \\
3 & Steroid & $x$ & $x$ \\
4 & Saponin & $\checkmark$ & $\checkmark$ \\
5 & Flavonoid & $\checkmark$ & $\checkmark$ \\
6 & Fenol & $\checkmark$ & $\checkmark$ \\
7 & Tanin & $\checkmark$ & $\checkmark$ \\
\hline
\end{tabular}

Dari ketujuh senyawa yang diuji, dapat dilihat bahwa daun kering $C$. odorata positif mengandung senyawa saponin, flavonoid, fenol dan tanin. Sedangkan ketiga senyawa lainnya yaitu alkaloid, terpenoid, dan steroid menunjukkan hasil yang negatif. Daun segar $C$. odorata positif mengandung senyawa alkaloid, saponin, flavonoid, fenol dan tanin. Sedangkan kedua senyawa lainnya yaitu terpenoid, dan steroid menunjukkan hasil yang negatif.

\section{Alkaloid}

Uji kandungan alkaloid ekstrak daun kering $C$ odorata secara kualitatif menunjukkan respon negatif terhadap keberadaan alkaloid sedangkan pada ekstrak daun segar C. odorata menunjukkan respon positif terhadap keberadaan alkaloid. Keberadaan alkaloid ditandai dengan terbentuknya endapan berwarna kemerahan pada uji alkaloid dengan pereaksi Dragendorff [18, 19]. Pereaksi Dragendorff merupakan campuran dari bismut nitrat yang bereaksi dengan kalium iodida menghasilkan endapan hitam bismuth(III) iodida, kemudian endapan tersebut larut dalam kalium iodida berlebih membentuk kalium tetraiodobismutat [19]. Alkaloid merupakan senyawa metabolit sekunder yang memiliki atom nitrogen terbanyak, senyawa ini sering ditemukan dalam jaringan tumbuhan dan hewan. Senyawa alkaloid sebagian besar bersumber dari tumbuh-tumbuhan. Alkaloid bersifat basa, sehingga dapat mengganti basa mineral dalam mempertahankan kesetimbangan ion dalam tumbuhan. Alkaloid pada tumbuhan berfungsi sebagai racun yang dapat melindunginya dari herbivora dan serangga, faktor pengatur pertumbuhan, dan senyawa simpanan yang mampu menyuplai nitrogen dan unsur-unsur lain yang diperlukan tanaman. Alkaloid dapat ditemukan pada berbagai bagian tumbuhan, seperti daun, bunga, ranting, biji, kulit batang, 
dan akar. Pada umumnya alkaloid ditemukan dalam kadar yang kecil, untuk menghasilkan alkaloid harus dipisahkan dari campuran senyawa yang rumit yang berasal dari jaringan tumbuhan [20].

Senyawa alkaloid berkhasiat sebagai anti kanker, antiinflamasi, antitoksin, afrodisiaka, obat jantung, obat luka bakar dan lain-lain. Alkaloid tidak hanya memiliki aksi sentral namun juga memiliki aksi perifer, yaitu dengan membantu relaksasi otot polos corpus cavernosum yang memicu terjadinya ereksi. Alkaloid memiliki mekanisme sentral yaitu meningkatkan pelepasan nitrit oksida dari endothelial dan ujung saraf. Alkaloid meningkatkan dilatasi pembuluh darah pada alat kelamin pria. Selain itu juga dapat menginduksi vasodilatasi sehingga menimbulkan ereksi [21]. Alkaloid dapat meningkatkan pertumbuhan rambut dan memperbesar tangkai rambut [22], senyawa alkaloid juga digunakan sebagai anti diabetes, anti diare, anti malaria dan anti mikroba, akan tetapi senyawa golongan alkaloid perlu diidentifikasi karena beberapa senyawa golongan alkaloid bersifat racun, identifikasi ini berfungsi untuk mengetahui manfaat dari senyawa golongan alkaloid tersebut [20].

\section{Saponin}

Uji kandungan saponin ekstrak daun kering dan segar $C$. odorata secara kualitatif menunjukkan respon positif terhadap keberadaan saponin. Saponin memiliki glikosil sebagai gugus polar serta gugus steroid atau triterpenoid sebagai gugus nonpolar sehingga saat dikocok dengan air permukaannya bersifat aktif dan membentuk misel. Pada struktur misel gugus nonpolar menghadap kedalam sedangkan gugus polar menghadap keluar dan keadaan inilah yang tampak seperti busa [23]. Saponin memiliki berbagai kelompok glikosil yang terikat pada posisi $\mathrm{C}_{3}$, tetapi beberapa saponin memiliki dua rantai gula yang menempel pada posisi $\mathrm{C}_{3}$ dan $C_{17}$ [24]. Saponin merupakan senyawa sekunder yang banyak ditemukan pada tumbuhan yaitu pada bagian daun, buah, kulit, biji dan akar. saponin berfungsi sebagai sistem pertahanan. Uji saponin dinyatakan positif dapat dicirikan dengan adanya rasa pahit, pembentukan busa yang stabil pada larutan cair dan mampu membentuk molekul dengan kolesterol [25]. Saponin memiliki berbagai macam sifat biologis seperti kemampuan hemolitik, antimolluska, aktivitas antibakterial, efek hipokolesterolemia, aktivitas antivirus [24], dan antiprotozoa, serta aktivitas sitotoksik atau anti kanker [26]. Selain itu, senyawa saponin berkhasiat sebagai antifungi, antibakteri, menghambat pertumbuhan sel tumor dan memiliki kemampuan menurunkan kolesterol dalam darah. saponin memiliki kemampuan menghambat pertumbuhan bakteri maupun fungi [24], berperan sebagai antioksidan [27], dan dapat menurunkan konsentrasi kolesterol dalam darah [28].

\section{Flavanoid}

Uji kandungan flavonoid ekstrak daun kering dan segar $C$. odorata secara kualitatif menunjukkan respon positif terhadap keberadaan flavonoid. Flavanoid merupakan senyawa polar yang mudah larut dalam pelarut polar seperti metanol, etanol, butanol, aseton, dan lain-lain [1]. Flavonoid merupakan salah satu metabolit sekunder yang terdapat pada tumbuhan [29]. Pada tumbuhan, flavonoid terikat pada gula sebagai aglikon flavanoid dan glikosida, Gula yang terikat pada flavanoid mudah larut dalam air. Senyawa flavonoid berfungsi sebagai Antioksidan, antimikroba, antivirus bagi tumbuhan, anti HIV, antitumor, antifungal, analgesik, antidiare, antihepatotoksik, antiradang, immuno stimulant, antihiperglikemik, sebagai vasolidator [1], obat infeksi pada luka, antivirus, antijamur, antibakteri, sitotoksik, anti hipertensi [29], anti kanker, antialergi, antioksidan, antiinflamasi. Flavonoid yang terdapat dalam buah dan sayuran segar dapat bermanfaat sebagai obat, salah satunya yaitu untuk mengurangi resiko stroke dan penyakit jantung. Senyawa Flavonoid dapat menghambat pertumbuhan sel kanker [30].

\section{Fenol}

Uji kandungan fenol ekstrak daun kering dan segar $C$. odorata secara kualitatif menunjukkan respon positif terhadap keberadaan fenol. Fenol merupakan senyawa metabolit sekunder yang dihasilkan oleh tumbuhan sebagai respon terhadap stres lingkungan. Senyawa fenol berfungsi sebagai pelindung terhadap sinar UV$B$ dan kematian sel untuk melindungi DNA dari dimerisasi dan kerusakan [31]. Fenol merupakan senyawa yang mempunyai sifat toksik [32] bakteriosid, antimetik, antiasmatik, antihelmintik, analgetik, antimikroba, antiinflamasi, meningkatkan mortilitas usus [33]. Senyawa ini memiliki peran penting sebagai agen pencegah dan pengobatan beberapa gangguan penyakit seperti arteriosklerosis, disfungsi otak, diabetes dan kanker [34]. Air limbah yang mengandung fenol sangat berbahaya bagi organisme akuatik dan dapat menghasilkan rasa tidak enak dan bau bahkan pada konsentrasi rendah [35].

\section{Tanin}

Uji kandungan tanin ekstrak daun kering dan segar $C$. odorata secara kualitatif menunjukkan respon positif terhadap keberadaan tanin. Tanin 
adalah salah satu senyawa metabolit sekunder yang dihasilkan oleh tumbuhan dan disintesis oleh tumbuhan. Tanin mempunyai berat molekul 500-3000 dan mengandung sejumlah besar gugus hidroksi fenolik yang memungkinkan terbentuknya ikatan silang yang efektif dengan protein dan molekul-molekul lain seperti asam amino, polisakarida, asam nukleat dan asam lemak [25]. Tanin juga merupakan salah satu senyawa organik polifenol yang jika direaksikan dengan besi akan menghasilkan warna yang gelap [36]. Senyawa tanin berfungsi sebagai pelindung diri dari serangan hewan pemakan tumbuhan [37] dan sebagai antibakteri [1].

\section{KESIMPULAN}

Daun kering $C$. odorata positif mengandung senyawa metabolit sekunder diantaranya saponin, flavonoid, fenol dan tanin. Daun segar C. odorata positif mengandung senyawa metabolit sekunder diantaranya alkaloid, saponin, flavonoid, fenol dan tanin.

\section{REFERENSI}

[1] Pratiwi, R. D. 2016. Uji Kualitatif Fitokimia Daun Ruta Angustifolia. Faktor Exacta. 9(3): 200-206.

[2] Mulyani, D. 2017. Perbandingan Daya Hambat Ekstrak Etanol Daun Kembang Bulan (Tithonia Diversifolia) dengan Daun Tekelan (Chromolaena odorata) terhadap Bakeri Staphylococcus aureus. Scientia. 7(2): 77-82.

[3] Fitrah, M. 2016. Identifikasi Ekstrak Daun Kopasanda (Chromolaena odorata Linn) Terhadap Sel Antiproliferasi Tikus Leukemia L1210. Jf Fik Uinam. 4(3):99-105.

[4] Chakraborty, A.K., Rambhade, S. dan Patil, U.K. 2011. Chromolaena odorata (L.): An Overview. Journal of Pharmacy Research. 4(3): 573-576.

[5] Fitrah, M., Winarno, H., dan Simanjuntak, P. 2017. Isolasi dan Identifikasi Senyawa Kimia Zat Anti Kanker dari Daun Kopasanda (Chromolaena odorata (L.)). Jurnal IImu Kefarmasian Indonesia. 15 (1): 77-81.

[6] Jumaat, S. R., Alimuddin, E.W., Lee, S. Y., Adam, A. Z., dan Mohamed, R. 2017. Preliminary Phytochemical Screening of Chromolaena odorata: A Non-Native Aromatic Plant Species at Ayer Hitam Forest Reserve, Selangor. The Malaysian Forester. 80(2):141-149.

[7] Saputra, A., Gani, A., dan Erlidawati. 2017. Uji Aktivitas Antioksidan Daun Gulma Siam (Chromoleana odorata L.) dengan Metode
1,1-Difenil-2-Pikrilhidrazil. Jurnal Ipa dan

Pembelajaran Ipa (JIPI). 1(2): 131-142.

[8] Chakraborty, S., Bhattacharya, T., Patel, T.N., dan Tiwari, K.K.. 2010. Biodegradation of Phenol By Native Microorganism Isolated From Coke Processing Wastewater. Journal of Environmental Biology. 31(1): 293-296.

[9] Ugwoke, C. E. C., Orji, J., Anze, S. P. G., dan Ilodibia, C. V. 2017. Quantitative Phytochemical Analysis and Antimicrobial Potential of The Ethanol and Aqueous Extracts of The Leaf, Stem and Root of Chromolaena odorata (Asteraceae). International Journal of Pharmacognosy and Phytochemical Research. 9(2): 207-214.

[10] Kouame, P. B. K., Jacques, C., Bedi, G., Silvestre, V., Loquet, D., Barillé-Nion, S., Robins, R. J., dan Tea, I. 2013. Phytochemicals Isolated From Leaves of Chromolaena odorata: Impact on Viability and Clonogenicity of Cancer Cell Lines. Phytotherapy Research. 27(6): 835-840.

[11] Vaisakh, M. N., dan Pandey, A. 2012. The Invasive Weed With Healing Properties: A Review on Chromolaena odorata. Int. J. Pharm Sci. Res.3(1): 80-83.

[12] Joshi, R. K. 2013. Chemical Composition of The Essential Oils of Aerial Parts and Flowers of Chromolaena odorata (L.) R. M. King dan $\mathrm{H}$. Rob. From Western Ghats Region of North West Karnataka, India. Journal of Essential Oil Bearing Plants. 16(1): 71-75.

[13] Panyaphu, K., On TV., Sirisa-Ard, P., SrisaNga, P., Chansakaow, S., dan Nathakarnkitkul S. 2011. Medicinal Plants of The Mien (Yao) in Northern Thailand and Their Potential Value in The Primary Healthcare of Postpartum Women. Journal of Ethnopharmacology. 135(1): 226-237.

[14] Ngozi, I. M., Jude, I. C., dan Catherine, I. C. 2009. Chemical Profile of Chromolaena odorata L. (King And Robinson) Leaves. Pakistan Journal of Nutrition. 8(5): 521-524.

[15] Vijayaraghavan, K., Rajkumar, J., dan Seyed, M. A. 2017. Efficacy of Chromolaena odorata Leaf Extracts For The Healing of Rat Excision Wounds. Veterinarni Medicina. 62(10): 565-578.

[16] Nirwanto., Eriadi, A., dan Arifin, H. 2017. Toksisitas Akut Ekstrak Etanol Daun Kirinyuh (Chromolaena odorata (L) R.M. King \& H. Rob) pada Mencit Putih Jantan. Medical and Health Science Journal. 1(2): 31-40.

[17] Halimatussakdiah., Amna, U., dan Wahyuningsih, P. 2018. Preliminary Phytochemical Analisys and Larvicidal Activity of Edible Fern (Diflazium 
esculentum (Retz) Sw.) Exact Against Culex. Jurnal Natural. 18(3): 141-146.

[18] Lantah, P. L., Montolalu, L. A. D. Y., dan Reo, A. R. 2017. Kandungan Fitokimia dan Aktivitas Antioksidan Ekstrak Metanol Rumput Laut Kappaphycus alvarezii. Jurnal Media Teknologi Hasil Perikanan. 5(3): 167173.

[19] Asmara, A. P. 2017. Uji Fitokimia Senyawa Metabolit Sekunder dalam Ekstrak Metanol Bunga Turi Merah (Sesbania grandiflora $L$. Pers). Al-Kimia 5(1): 48-59.

[20] Ningrum, R., Purwanti, E., dan Sukarsono. 2016. Identifikasi Senyawa Alkaloid dari Batang Karamunting (Rhodomyrtus tomentosa) sebagai Bahan Ajar Biologi Untuk Sma Kelas X. Jurnal Pendidikan Biologi Indonesia. 2(3): 231-236.

[21] Fahruni., Handayani, R., dan Novaryatiin, S. 2018. Potensi Tumbuhan Kelakai (Stenochlaena palustris (Burm.F.) Bedd) Asal Kalimantan Tengah sebagai Afrodisiaka. Jurnal Surya Medika. 3(2): 144153.

[22] Jubaidah, S., Indriani, R., Sa'adah, H., Dan Wijaya, H. 2018. Formulasi dan Uji Pertumbuhan Rambut Kelinci dari Sediaan Hair Tonic Kombinasi Ekstrak Daun Seledri (Apium graveolens Linn) dan Daun Mangkokan (Polyscias scutellaria (Burm.F.) Fosberg). Jurnal Ilmiah Manuntung. 4(1): 814.

[23] Habibi, A. I., Firmansyah, R. A., dan Setyawati, S. M. 2018. Skrining Fitokimia Ekstrak n-heksan Korteks Batang Salam (Syzygium polyanthum). Indonesian Journal Of Chemical Science. 7(1): 1-4.

[24] Yanuartono., Purnamaningsih, H., Nururrozi, A., dan Indarjulianto, S. 2017. Saponin: Dampak Terhadap Ternak (Ulasan). Jurnal Peternakan Sriwijaya. 6(2): 79-90.

[25] Hidayah, N. 2016. Pemanfaatan Senyawa Metabolit Sekunder Tanaman (Tanin dan Saponin) dalam Mengurangi Emisi Metan Ternak Ruminansia. Jurnal Sain Peternakan Indonesia. 1(2): 89-98.

[26] Agarwal, A. 2016. Duality Of Anti-Nutritional Factors in Pulses. J Nutr Disorders Ther. 6 (1): 1-2.

[27] Mawan, A. R., Indriwati, S. E., dan Suhadi. 2018. Aktivitas Antibakteri Ekstrak Metanol Buah Syzygium Polyanthum terhadap Pertumbuhan Bakteri Escherchia Coli. Bioeksperimen. 4(1): 64-68.

[28] Vinarova, L., Z. Vinarov, V. Atanasov, I. Pantcheva, S. Tcholakova, N. Denkova, dan S. Stoyanov. 2015. Lowering of Cholesterol Bioaccessibility and Serum Concentrations by Saponins: In Vitro And In Vivo Studies. Food Funct. 6: 501-512.
[29] Dewi, S. T. R., dan Wahyuni, S. 2018. Uji Efek Anti Inflamasi Rebusan Daun Jamblang (Syzygium cumini) pada Mencit (Mus musculus). Media Farmasi. 14(1): 5359.

[30] Mutrikah., Santoso, H., Dan Sauqi, A. 2018. Profil Bioaktif pada Tanaman Temulawak (Curcuma xanthorriza Roxb) dan Beluntas (Pluchea indica Less). BIOSAINTROPIS. 4(1): 15-21.

[31] Hanin, N. N. F., dan Pratiwi, R. 2017. Kandungan Fenolik, Flavonoid dan Aktivitas Antioksidan Ekstrak Daun Paku Laut (Acrostichum aureum L.) Fertil Dan Steril. Journal Of Tropical Biodiversity And Biotechnology. 2 (1): 51-56.

[32] Oktaviani, Z.P. And Haris, A. 2016. Sintesis Zno-Sio 2 dan Aplikasinya pada Fotokatalis Degradasi Limbah Organik Fenol dan Penurunan Kadar Cd(II) secara Simultan. Journal Kimia Sains Dan Aplikasi. 19(2): 4549.

[33] Tahir, M., Muflihunna, A., dan Syafrianti. 2017. Penentuan Kadar Fenolik Total Ekstrak Etanol Daun Nilam (Pogostemon cablin Benth.) dengan Metode Spektrofotometri UV-Vis. Jurnal Fitofarmaka Indonesia. 4(1): 215-218.

[34] Garg, N., Abdel-Aziz, S.M., dan Aeron, A. 2016. Microbes in Food and Health, Springer. Switzerland 42-45.

[35] Bernal, A.M., Granados, F.G., Giraldo, L. dan Pirajan, J.C.M. 2017. Application of The Sips Model to The Calculation of Maximum Adsorption Capacity and Immersion Enthalpy of Phenol Aqueous Solutions on Activated Carbons. European Journal Of Chemistry. 8 (2) : 112-118.

[36] Nurjannati, M., Winarsi, H., dan Dwiyanti, H. 2018. Efek Lama Perkecambahan Terhadap Sifar Sensori dari Kadar Protein Terlarut Susu Kecambah Kacang Merah (Sukarah) untuk Remaja Obesitas. J. Gipas. 2(2): 27-42.

[37] Sarifudin, A., Wardatun, S., dan Wiendarlina 2018. Kajian Metode Pengeringan dan Metode Analisis Daun Belimbing Wuluh (Avverrhoa bilimbi L.) Terhadap Kadar Tanin. Jurnal Online Mahasiswa Bidang Farmasi. 1(1): 1-9. 